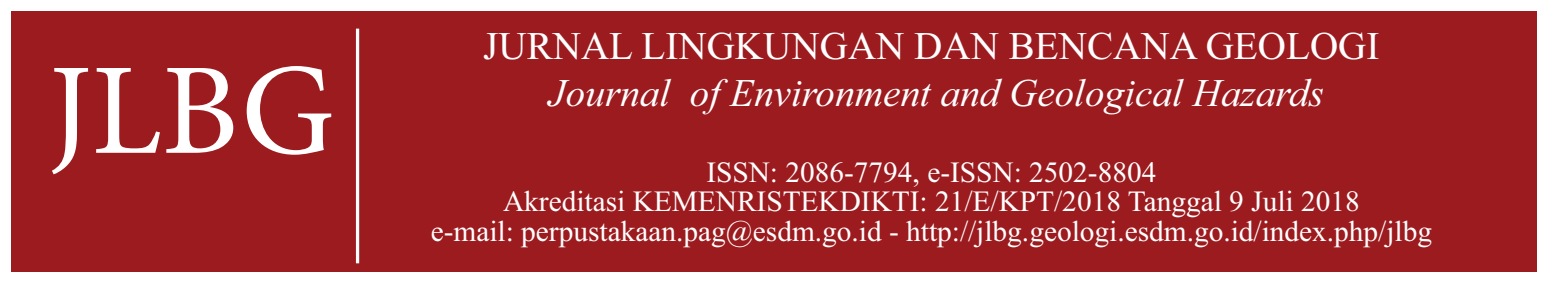

\title{
Metode Geolistrik Konfigurasi Dipole-Dipole Untuk Penetapan Bidang Gelincir Gerakan Tanah di Jajaway, Palabuhanratu, Sukabumi
}

\section{Geoelectrical Method With Dipole-Dipole Configuration For Identifying The Landslide Slip Surface in Jajaway, Palabuhanratu, Sukabumi}

\author{
Shinta Kiky Rachmawati ${ }^{1}$, Yayat Sudradjat ${ }^{2}$, Lina Handayani ${ }^{2}$, Dadan Dani Wardhana ${ }^{2}$ \\ ${ }^{1}$ Fakultas Sains Institut Teknologi Sepuluh Nopember \\ Jl. Raya ITS, Keputih, Kec. Sukolilo, Kota SBY, Jawa Timur, 60117, Indonesia \\ ${ }^{2}$ Pusat Penelitian Geoteknologi, LIPI \\ Jl. Sangkuriang, Bandung, 40135, Indonesia \\ e-mail: lina.handayani@gmail.com \\ Naskah diterima 13 Januari 2020, selesai direvisi 20 April 2021, dan disetujui 30 April 2021
}

\begin{abstract}
ABSTRAK
Gerakan tanah di kompleks perkantoran Kabupaten Sukabumi di Jajaway, Palabuhanratu, terjadi di luar perkiraan dan perencanaan pembangunan sebelumnya. Untuk melihat kondisi dan luasan daerah gerakan tanah dan dalam usaha mengurangi resiko kerugian lebih besar, diperlukan identifikasi bidang gelincir gerakan tanah di kompleks tersebut. Bidang gelincir dicari berdasarkan model tahanan jenis yang diperoleh dari survei pengukuran geolistrik. Akuisisi data dilakukan pada 7 lintasan, dengan 6 lintasan berarah utara-selatan dan 1 lintasan berarah barat-timur. Metode akusisi yang digunakan adalah tahanan jenis multielektrode dengan konfigurasi dipole-dipole. Hasil penelitian membuktikan bahwa kondisi perlapisan batuan lepas tetapi lebih berat di atas lapisan lempung merupakan salah satu penyebab kejadian pergerakan tanah. Kejadian itu sangat terlokalisir karena kondisi seperti itu tidak ditemukan pada lintasan lainnya.

Kata kunci: bidang gelincir, geolistrik, gerakan tanah, konfigurasi dipole-dipole, tahanan jenis
\end{abstract}

\section{ABSTRACT}

Ground movement in the Sukabumi Regency office complex (Jajaway, Palabuhanratu), occured unexpectedly. To reduce the potential risk, we need to identify the slip surface to detect the possibilities of more landslides. Resistivity model by the dipole-dipole geoelectrical method was applied to find the slip surface. Data acquisition was carried out in 7 lines: 6 north-south lines and 1 east-west line. The resistivity models present the distribution of resistivity below the surface. Above this clay layer, there is a higher resistivity layer, which is related to sandy tuff and breccia. The condition might cause the previous creeping type of ground movement. The type of layering is not found in the other lines. Therefore we do not expect a similar ground movement would occur in those lines.

Keywords: dipole-dipole configuration, geoelectrical, landslide, resistivity, slip surface

\section{PENDAHULUAN}

Kompleks perkantoran pemerintah daerah Kabupaten Sukabumi di Jajaway dibangun di daerah bukaan baru di Palabuhanratu. Saat pembangunan masih berjalan, terjadi gerakan tanah di salah satu bagian yang masih berupa tanah kosong, sehingga tidak ada kerugian ataupun korban. Untuk mengantisipasi kejadian yang sama, diperlukan pengamatan kemungkinan gerakan tanah di daerah ini sebelum pembangunan gedung dilanjutkan.

Gerakan tanah adalah proses berpindahnya atau bergeraknya tanah, batuan, campuran tanah dan batuan penyusun lereng menuruni lereng atau keluar lereng (Highland and Bobrowsky, 2008). Gerakan tanah sangat dipengaruhi 
oleh kondisi topografi, litologi, stratigrafi dan struktur geologi (Keskinsezer and Dağ, 2019). Fenomena ini cukup berbahaya karena dapat menimbulkan korban jiwa, kerugian materiil, rusaknya sarana dan prasarana pada masyarakat lokal. Curah hujan yang tinggi dapat memicu adanya gerakan tanah, karena saat curah hujan tinggi, air yang masuk ke dalam pori-pori tanah mencapai lapisan impermeable. Air yang tidak dapat terserap menyebabkan lapisan impermeable licin sehingga terjadilah gerakan tanah. Air hujan akan lebih mudah membuat jenuh lereng karena adanya zona-zona air yang terperangkap yang meningkatkan tekanan pori dalam tanah (Putra et al., 2020; Schulz et al., 2017).

Salah satu penyebab gerakan tanah atau longsoran adalah adanya bidang gelincir (slip surface) atau bidang geser (shear surface) di mana gerakan tanah (longsoran) akan terjadi di atas lapisan ini. Untuk mendeteksi adanya bidang geser atau bidang gelicir, perlu dilakukan identifikasi dengan pengamatan bawah permukaan. Penelitian menggunakan metode geolistrik tahanan jenis dapat memberikan model bawah permukaan dengan kedalaman yang tepat untuk mendeteksi adanya bidang gelincir. Penggunaan geolistrik sudah sangat umum dilakukan dan terbukti efektifitasnya pada penelitian berbagai tipe gerakan tanah (e.g. Bellanova et al., 2018; Cebulski et al., 2020; Keskinsezer dan Dağ, 2019; Ling et al., 2016; Putra et al., 2020; Rauff et al., 2020).

Palabuhanratu termasuk ke dalam rangkaian pegunungan selatan Jawa Barat (Van Bemmelen, 1949). Berdasarkan peta geologi (Gambar 1), daerah Palabuhanratu ditutupi oleh aluvium berupa lempung, kerikil dan kerakal, endapan sungai termasuk pasir dan kerikil. Selain itu, juga tersusun dari material gunung api muda yang batuan-batuannya belum mengalami pemadatan sehingga kekuatannya sangat rendah (Effendi et al., 1998).

Palabuhanratu merupakan daerah dataran dengan lapisan sedimen lepas aluvial yang tebal. Kondisi tersebut menjadikan daerah ini merupakan daerah rawan gerakan tanah. Beberapa laporan dan penelitian terdahulu menyatakan daerah Palabuhanratu sebagai salah satu daerah yang termasuk ke dalam zona kerentanan rendah

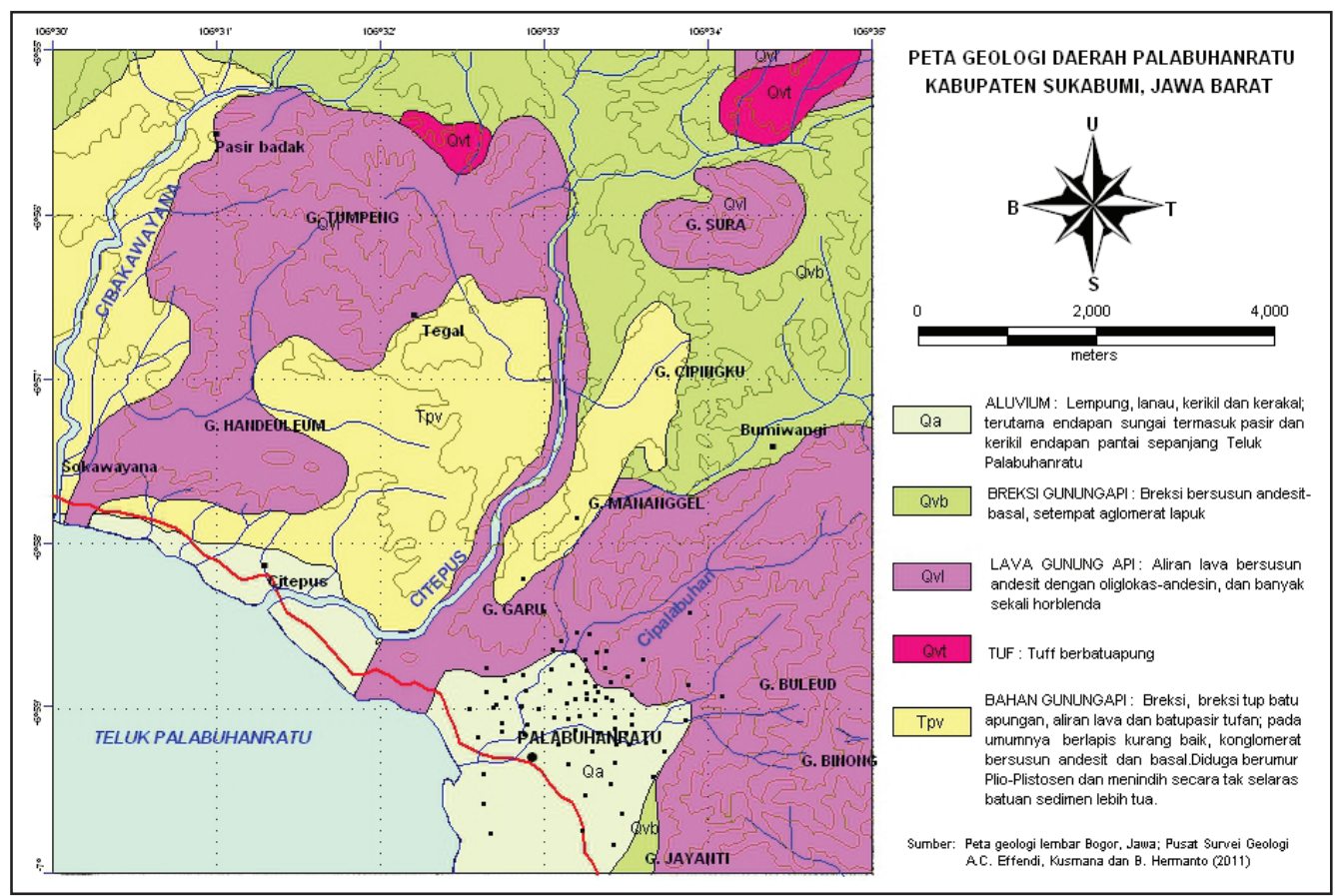

Gambar 1. Peta geologi daerah Palabuhanratu. Kotak merah adalah daerah penelitian dengan detil di Gambar 5 (Sumber peta: Effendi et al., 1998). 
hingga menengah (e.g., PVMBG, 2020; Sugianti et al., 2016).

\section{METODE PENELITIAN}

Prinsip dasar metode geolistrik berpedoman pada Hukum Ohm yang menggambarkan hubungan antara kuat arus listrik, beda potensial dan hambatan (Telford et al., 1990) atau ditulis sebagai:

$$
I=\frac{V}{R}
$$

Di mana $V$ adalah beda potensial (Volt), $I$ adalah kuat arus listrik (Ampere), dan $\mathrm{R}$ adalah Hambatan (Ohm). Metode tahanan jenis pada umumnya menggunakan setidaknya empat buah elektrode. Dua buah elektrode arus atau current dipole $\left(\mathrm{C}_{1} \mathrm{C}_{2}\right)$ dan dua elektrode potensial atau potential dipole $\left(\mathrm{P}_{1} \mathrm{P}_{2}\right)$. Skema injeksi arus dapat dilihat pada Gambar 2.

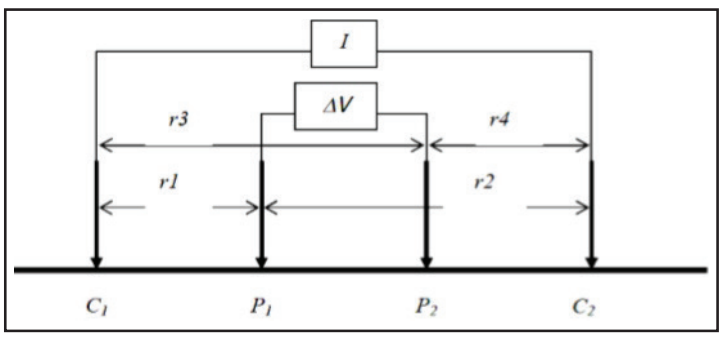

Gambar 2. Skema dua elektrode arus dan potensial terletak di permukaan tanah homogen isotropis (Telford et al., 1990)

Beda potensial di antara titik $\mathrm{P} 1$ dan $\mathrm{P} 2$ ditulis sebagai:

$$
\Delta V=V_{p 1}-V_{p 2}=\frac{I \rho}{2 \pi}\left[\left(\frac{1}{r_{1}}-\frac{1}{r_{2}}\right)-\left(\frac{1}{r_{3}}-\frac{1}{r_{4}}\right)\right] . .
$$

Tahanan jenis $\rho$ yang didapatkan dari persamaan di atas adalah:

$$
\rho=2 \pi\left[\frac{1}{r_{1}}-\frac{1}{r_{2}}-\frac{1}{r_{3}}+\frac{1}{r_{4}}\right]^{-1} \frac{\Delta V}{I}
$$

atau dapat disederhanakan menjadi:

$$
\rho=K \frac{\Delta V}{I}
$$

dengan $\mathrm{K}$ merupakan faktor geometri:

$$
K=2 \pi\left[\frac{1}{r_{1}}-\frac{1}{r_{2}}-\frac{1}{r_{3}}+\frac{1}{r_{4}}\right]^{-1}
$$

Konfigurasi elektrode dipole-dipole adalah salah satu jenis konfigurasi yang digunakan dalam metode geolistrik resisitivitas di mana $\mathrm{C}_{1}, \mathrm{C}_{2}$ digunakan sebagai elektrode potensial dan $\mathrm{P}_{1}, \mathrm{P}_{2}$ sebagai elektrode arus. Konfigurasi elektrode terdiri atas dipole-dipole elektrode arus dan elektrode potensial yang terpisah sejauh na (Gambar 3).

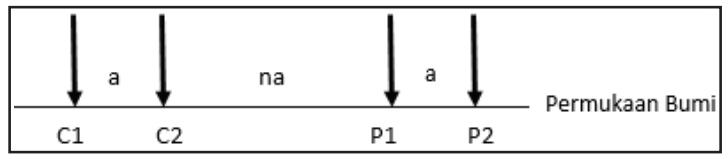

Gambar 3. Sketsa konfigurasi dipole-dipole (Telford et al., 1990).

Dalam konfigurasi dipole-dipole (Gambar 3), jarak antar elektrode arus sebesar a dan jarak antar elektrode potensial terpisah sejauh a. Variasi $\mathrm{n}$ digunakan untuk mendapatkan berbagai kedalaman tertentu. Semakin besar nilai n maka kedalaman yang didapatkan juga semakin besar. Tingkat sensitivitas konfigurasi dipole-dipole terhadap kedalaman dipengaruhi oleh nilai a dan n. Datum point atau titik pengukuran di bawah permukaan lintasan pengukuran merupakan titik tengah dari total spasi elektrode arus dan tegangan. Letak datum point dapat ditunjukkan seperti pada Gambar 4.

Data lapangan diharapkan dapat memberikan informasi sifat fisis batuan bawah permukaan dan kedalamannya. Informasi ini bisa didapatkan apabila mengetahui hubungan antara sifat fisis batuan dan data observasi. Hubungan ini berupa model matematika yang memungkinkan menentukan parameter fisis batuan. Dalam 


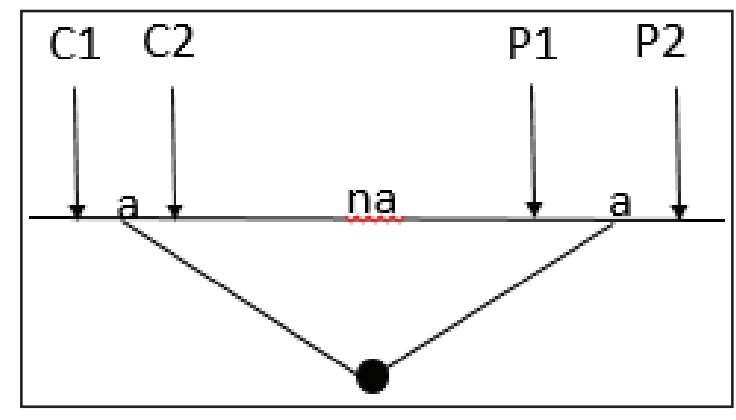

Gambar 4. Skema letak datum point konfigurasi dipoledipole (Telford et al., 1990).

permodelan data geofisika, dicari model yang menghasilkan respon yang cocok dengan data pengukuran lapangan sehingga model tersebut dapat dianggap mewakili kondisi bawah permukaan lokasi pengukuran. Proses ini disebut dengan permodelan inversi (inverse modelling). Dalam proses inversi dilakukan pencocokan kurva (curvefitting) antarmodel matematika dan data eksperimen (Grandis, 2009).

Inversi dapat dideskripsikan sebagai:

$$
d_{i}=\int_{0}^{z} K_{i}(r) p(r) d r
$$

dengan $\mathrm{d}_{\mathrm{i}}$ merupakan respon data yang terukur, $p(r)$ merupakan fungsi yang berkaitan dengan parameter fisis yang dicari dan $K_{i}(r)$ disebut data kernel yang menjelaskan hubungan parameter fisis $p(r)$ dengan data lapangan. Parameter fisis dalam penelitian ini adalah tahanan jenis batuan. Persamaan di atas akan relatif mudah diselesaikan dengan pendekatan komputasi untuk menyederhanakan $p(r)$ menjadi $\mathrm{m}$, sementara $K_{i}$ menjadi $G_{i}$ sehingga persamaan dapat ditulis dalam bentuk diskrit menjadi:

$$
d_{i}=\sum G_{i j} m_{j}
$$

Pengukuran tahanan jenis semu bertujuan untuk mengetahui lapisan bawah permukaan daerah pengukuran. Apabila persamaan di atas tidak dapat mendekati fungsi parameter (tahanan jenis masing-masing lapisan) maka penyelesaian tahanan jenis semu disebut non linear. Salah satu metode untuk menyelesaikan permasalahan non linear adalah metode conjugate gradient (CG). Metode ini cukup efisien dalam menyelesaikan permasalahan sistem linier dengan skala besar (Rodi and Mackie, 2001). Inversi yang digunakan dalam penelitian ini adalah NLCG (Non Linier Conjugate Gradient) yang terdapat dalam software EarthImager.

\section{HASIL DAN PEMBAHASAN}

Akuisisi data dilakukan pada 7 lintasan pengukuran. Ada 6 lintasan dengan arah utara-selatan dan 1 lintasan dengan arah barat-timur (Gambar 5). Panjang lintasan bervariasi antara 270 meter dan 550 meter yang disesuaikan dengan kondisi lapangan. Elektrode yang digunakan sebanyak 56 buah dengan jarak antara elektrode 10 meter. Pengambilan data geolistrik dilakukan dengan konfigurasi multi elektrode dipole-dipole dengan menggunakan peralatan multichannel SuperSting R8-IR Resistivitymeter. Data yang didapat dari alat adalah data nilai arus dan tahanan jenis dengan format (.stg). Data tersebut digabungkan dengan data ketinggian elektrode (.trn), yang kemudian diolah dengan software EarthImager $2 D$ versi 2.2.2 untuk mendapatkan penampang sebaran nilai tahanan jenis bawah permukaan 2 dimensi. Hasil pengolahan data akan diinterpretasikan sesuai dengan kondisi lapangan dan geologi daerah pengukuran.

Hasil pemodelan 2D secara umum memperlihatkan variasi nilai tahanan jenis daerah penelitian antara 1,0 $\Omega \mathrm{m}$ (warna biru) -250 $\Omega \mathrm{m}$ (warna merah). Sumbu tegak sebelah kiri menunjukan elevasi (tinggi) berdasarkan tinggi elektrode dan sumbu tegak sebelah kanan menunjukan kedalaman dihitung dari elevasi tertinggi elektrode lintasan. Nilai tahanan jenis dipengaruhi oleh 2 faktor utama yaitu jenis batuan dan kandungan air (Telford et al., 1990). Nilai tahanan jenis tinggi berkaitan dengan jenis batuan keras dan kompak sedangkan nilai tahanan jenis rendah bersesuaian dengan jenis batuan lunak seperti lempung dan tufa pasiran. Tabel 1 menunjukkan nilai tahanan jenis, perkiraan jenis batuan, dan warna dalam penampang pemodelan. 


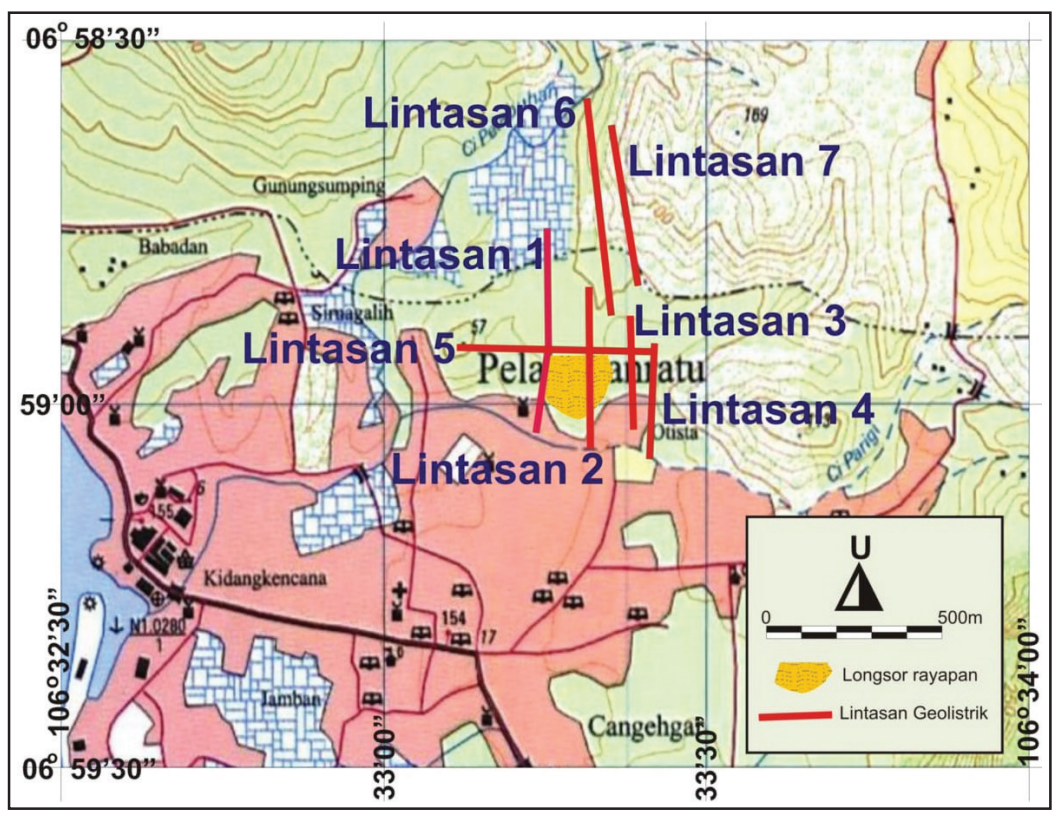

Gambar 5. Lintasan-lintasan pengukuran (garis merah). Satu lintasan berarah barat-timur (Lintasan 5), dan enam lintasan berarah utara-selatan (Lintasan 1, 2, 3, 4, 6, dan 7).

Tabel 1. Pelapisan Batuan berdasarkan nilai Tahanan Jenis

\begin{tabular}{|c|c|c|}
\hline Litologi & $\begin{array}{c}\text { Nilai } \\
\text { Tahanan Jenis } \\
(\Omega \mathrm{m})\end{array}$ & $\begin{array}{l}\text { Skala } \\
\text { Warna }\end{array}$ \\
\hline Lempung & $<5,5$ & \\
\hline Tufa, Tufa Pasiran & $5,5 \leq \mathrm{R} \leq 10$ & \\
\hline $\begin{array}{l}\text { Pasir, Kerikil, Breksi } \\
\text { Lapuk }\end{array}$ & $10 \leq \mathrm{R} \leq 30$ & \\
\hline $\begin{array}{l}\text { Breksi, Kerakal, Batu } \\
\text { Pasir }\end{array}$ & $30 \leq \mathrm{R} \leq 100$ & \\
\hline Breksi Kompak, Bolder & $\geq 100$ & \\
\hline
\end{tabular}

Dari hasil pengolahan data pada Lintasan 1 diperoleh penampang 2D seperti pada Gambar 6. Model penampang Lintasan 1 memiliki error sebesar 3,62\% dengan 7 kali iterasi dan kedalaman mencapai 122 meter. Warna biru memiliki nilai tahanan jenis rendah $\leq 5 \Omega \mathrm{m}$ diinterpretasikan sebagai lempung yang dominan di sisi selatan lokasi. Daerah berwarna merah dominan di sisi utara dengan nilai tahanan jenis tinggi $\geq 30 \Omega \mathrm{m}$ diinterpretasikan sebagai pasir, breksi dan kerakal. Pada Gambar 6 terdapat bidang batas antara batuan yang bersifat keras (breksi dan kerakal) dengan tanah lempung yang bersifat lunak dan sulit dilalui air. Bidang batas tersebut berada pada jarak 240 meter dari titik 0 (pertemuan daerah hijau dan biru).

Hasil pengolahan data pada Lintasan 2 dapat dilihat pada Gambar 7. Model tahanan jenis Lintasan 2 memiliki error 2,07\% dengan iterasi 7 kali dan kedalaman yang dicapai 100 meter. Lintasan ini memiliki spasi elektrode 10 meter dengan panjang lintasan 440 meter. Warna hijaukuning memiliki nilai tahanan jenis sedang < $100 \Omega \mathrm{m}$ dimulai pada kedalaman 0-50 meter diinterpretasikan sebagai pasir, breksi lapuk, kerikil. Warna biru dengan nilai tahanan jenis rendah $<5,5 \Omega \mathrm{m}$ berada di kedalaman $>50$ meter di bawah permukaan bumi diidentifikasikan sebagai lempung. Pertemuan antara lempung dan sedimen di atasnya sangat mungkin merupakan bidang gelincir (garis merah putus-putus).

Model hasil pengolahan data pada Lintasan 3 dapat dilihat pada Gambar 8, yang memiliki nilai error 2,22\%, dari iterasi sebanyak 6 kali, dengan kedalaman yang dicapai 74 meter di bawah permukaan. Spasi elektrode yang digunakan 10 meter dengan panjang lintasan 270 meter. Hasil 


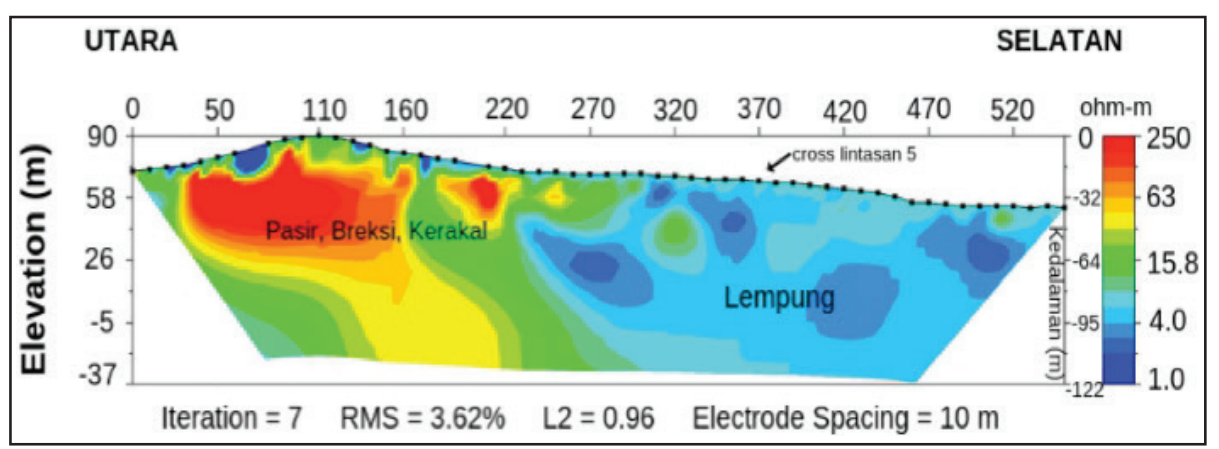

Gambar 6. Penampang 2D hasil pengolahan pada Lintasan 1.

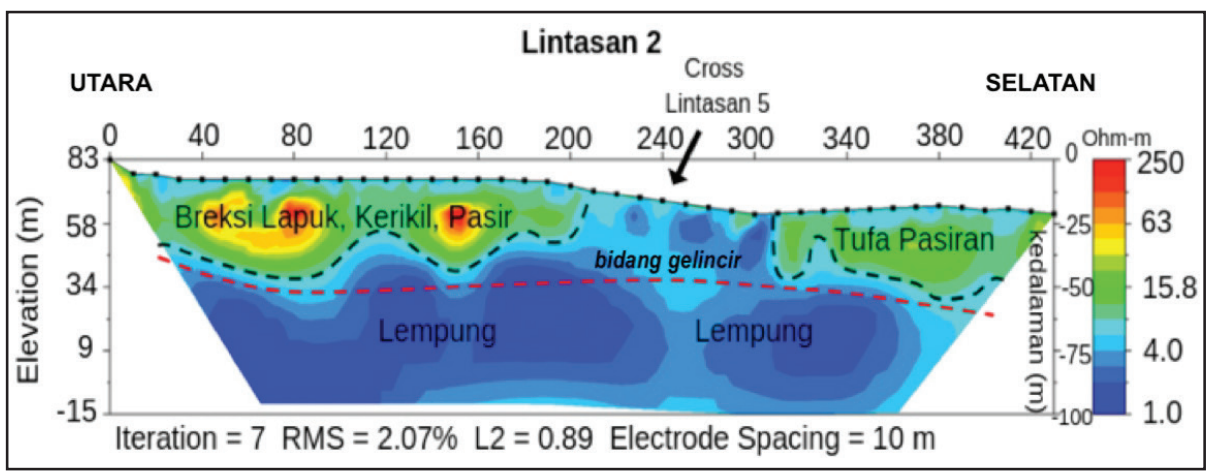

Gambar 7. Penampang 2D hasil pengolahan pada Lintasan 2.

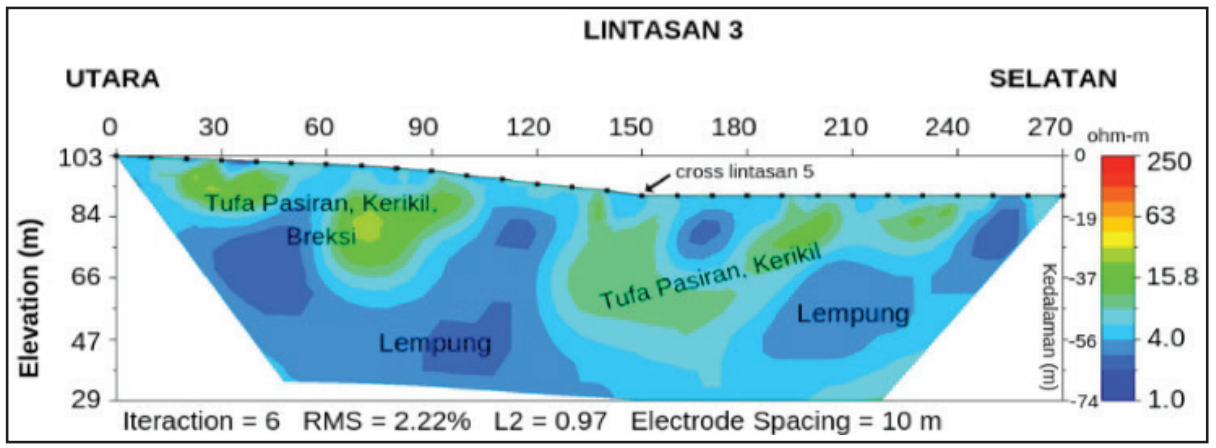

Gambar 8. Penampang 2D hasil pengolahan pada Lintasan 3.

pengolahan menunjukan kondisi bawah permukaan lintasan 3 didominasi warna biru dengan nilai tahanan jenis $\leq 5,5 \Omega \mathrm{m}$ diinterpretasikan sebagai tanah lempung dan warna hijau diinterpretasikan sebagai tufa pasiran dan kerikil.

Hasil pengolahan data Lintasan 4 dapat dilihat pada Gambar 9. Model memiliki nilai error $1,78 \%$ dari iterasi sebanyak 6 kali. Spasi elektrode yang digunakan 10 meter dengan panjang lintasan 270 meter. Hasil pengolahan menunjukan bahwa bawah permukaan lintasan
4 memiliki dua kelompok nilai tahanan jenis: 10-30 $\Omega \mathrm{m}$ yang diinterpretasikan sebagai tufa pasiran, pasir, kerikil (warna hijau-kuning) dan $\geq 30 \Omega$ m yang diinterpretasikan sebagai batuan keras breksi (warna kuning merah).

Model hasil pengolahan data pada Lintasan 5 dapat dilihat pada Gambar 10, yang memiliki nilai error 1,39\%, dari 4 kali iterasi. Kedalaman yang dicapai 90 meter. Spasi elektrode yang digunakan 10 meter dengan panjang lintasan 270 meter. Penampang model tahanan jenis 


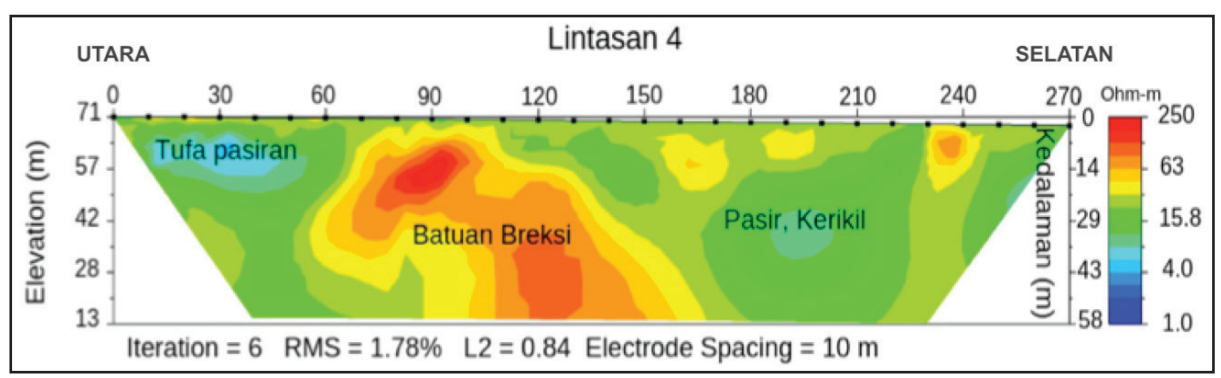

Gambar 9. Penampang 2D hasil pengolahan pada Lintasan 4.

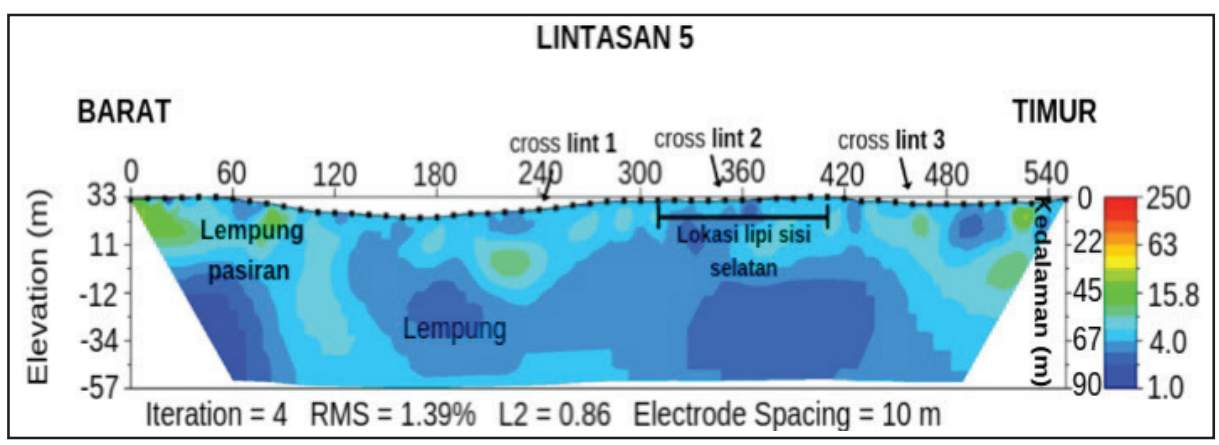

Gambar 10. Penampang 2D hasil pengolahan pada Lintasan 5.

menunjukan kondisi bawah permukaan lintasan ini didominasi warna biru dengan nilai tahanan jenis $\leq 5.5 \Omega \mathrm{m}$ yang diinterpretasikan sebagai tanah lempung dan lempung pasiran.

Penampang 2D hasil pengolahan Lintasan 6 dapat dilihat pada Gambar 11. Error pada model lintasan ini sebesar $1,82 \%$ dari 6 kali iterasi dan panjang lintasan 550 meter terbentang dari utara ke selatan. Penampang model Lintasan 6 menunjukan nilai tahanan jenis 30-100 $\Omega \mathrm{m}$ (warna kuning-merah) yang diinterpretasikan sebagai breksi dan kerakal pada kedalaman 0-25 meter. Nilai tahanan jenis $10-30 \Omega \mathrm{m}$ (warna biru-hijau) diinterpretasikan sebagai tufa pasiran pada kedalaman $\geq 25$ meter.
Hasil pemodelan Lintasan 7 dapat dilihat pada Gambar 12 dengan nilai error sebesar 1,84\% dan jumlah iterasi 6 kali. Panjang lintasan pengukuran 410 meter terbentang dari utara ke selatan. Kedalaman yang dicapai adalah 135 meter. Lapisan bawah permukaan lintasan ini didominasi dengan batuan keras barupa breksi kompak, kerakal dan batu pasir dengan nilai tahanan jenis $\geq 100 \Omega \mathrm{m}$ (warna orange-merah). Ada pasir, breksi lapuk dan tufa pasiran dengan nilai tahanan jenis $5,5 \Omega \mathrm{m}-50 \Omega \mathrm{m}$ (warna biruhijau).

Untuk melihat semua penampang bawah permukaan secara menyeluruh, ketujuh penampang disusun secara 3 dimensi seperti pada Gambar 13.

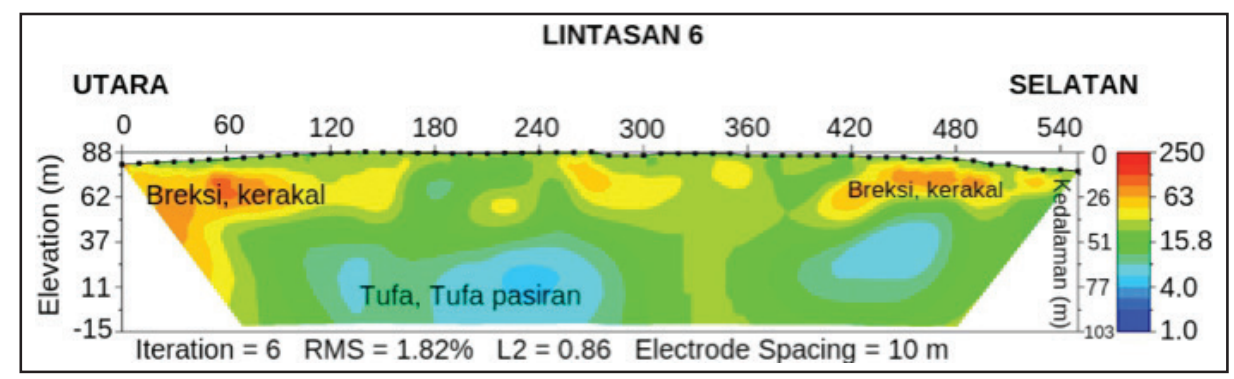

Gambar 11. Penampang 2D hasil pengolahan pada Lintasan 6. 


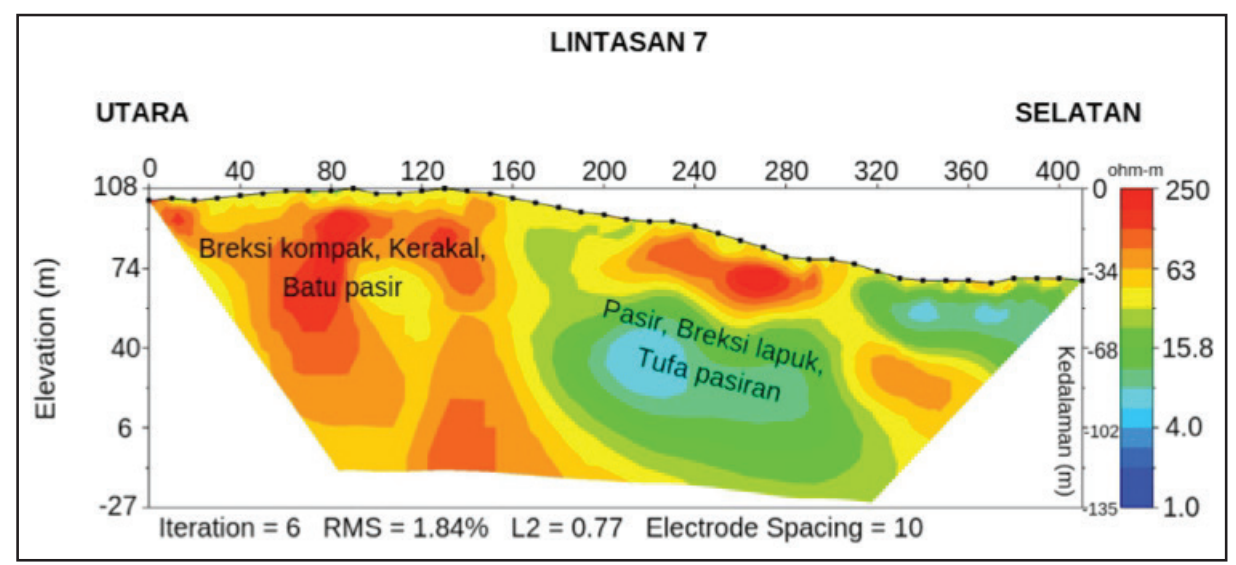

Gambar 12. Penampang 2D hasil pengolahan pada Lintasan 7.

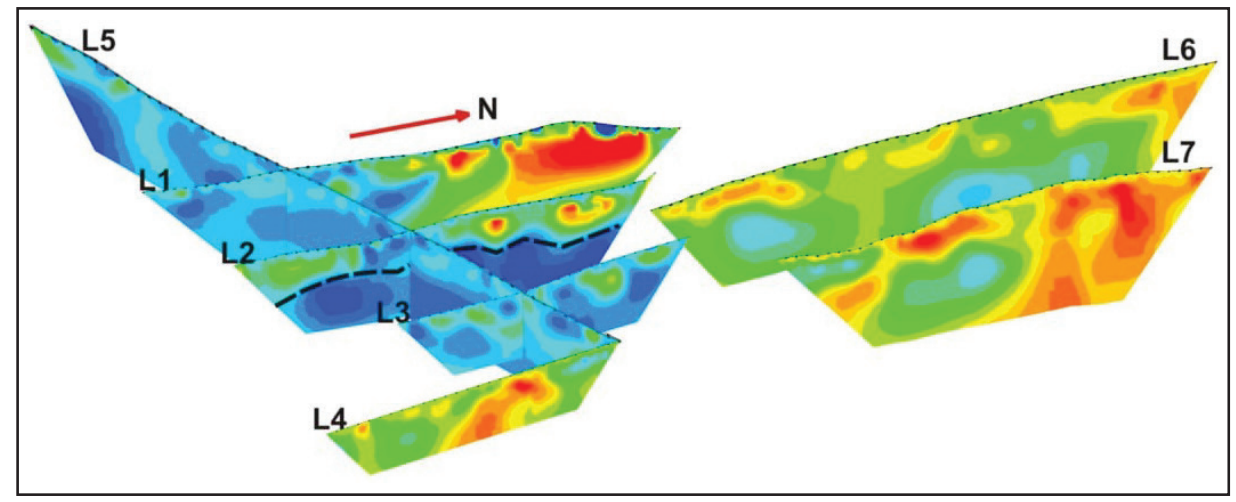

Gambar 13. Sketsa 3 dimensi seluruh penampang model tahanan jenis (L1- L7). Garis hitam putus-putus adalah dugaan bidang gelincir.

Hasil korelasi tersebut menunjukan dengan jelas letak zona bidang gelincir tanah longsor yang terdapat di Lintasan 2 daerah penelitian. Bidang gelincir (slip surface) terletak di antara 2 jenis lapisan tanah yang memiliki nilai tahanan jenis kontras, yaitu bidang yang stabil dengan bidang bergerak atau bidang tergelincir. Pada kasus kompleks daerah penelitian ini, bidang gelincir tampaknya berada di antara batuan lempung dengan batuan sedimen lepas di atasnya. Pergerakan tanah dapat terjadi karena nilai tahanan jenis lapisan bagian atas lebih besar dari lapisan bawah. Apabila ada gaya pendorong lebih besar daripada gaya penahan di sepanjang lereng tersebut, maka potensi gerakan tanah akan semakin besar. Gaya dorong dipengaruhi oleh intensitas hujan, kondisi bawah permukaan dan lapisan kedap air (impermeable) (Radbruch-Hall and Varnes,
1976). Tanah aluvial berupa lempung yang impermeable pada kondisi kemiringan lereng tertentu dan curah hujan yang tinggi dapat menyebabkan pergerakan tanah. Jika air hujan menembus sampai ke lapisan impermeable yang berperan sebagai bidang gelincir, tanah akan licin dan tanah pelapukan di atasnya akan turun menuruni lereng.

Pada Gambar 13, tampak lapisan dengan nilai tahanan jenis lebih besar dari $30 \Omega \mathrm{m}$ dominan berada di bagian utara, menipis ke selatan pada Lintasan 1 dan Lintasan 2. Lapisan bertahanan jenis tinggi ini tidak terlihat pada Lintasan 5 . Pada bagian selatan didominasi oleh lempung, tufa pasiran yang memiliki nilai tahanan jenis kurang dari $30 \Omega \mathrm{m}$. Pada bagian timur dapat dilihat batas antara tanah lempung yang bersifat lunak dan impermeable (Lintasan 3) dengan batuan bersifat keras (Lintasan 4). Zona bidang 
gelincir berada di Lintasan 2 membentang dari utara ke selatan. Pergerakan tanah terjadi ke arah selatan menuruni lereng. Jenis gerakan tanah longsor yang mungkin terjadi adalah jenis rayapan (creeping).

\section{KESIMPULAN}

Pencitraan bawah permukaan berdasarkan data tahanan jenis menunjukkan posisi rinci letak bidang gelincir di kompleks perkantoran yang diteliti. Bidang gelincir hanya terdeteksi pada satu lintasan, yaitu Lintasan 2. Lintasan lainnya tidak menunjukkan adanya kehadiran bidang gelincir. Secara umum area perkantoran ini cukup aman dari bahaya gerakan tanah, terutama sisi utara dan timur. Kehati-hatian diperlukan pada pembangunan infrastruktur di sisi barat di mana lapisan lempung mendominasi bawah permukaannya. Pengamatan geologi teknik sangat disarankan untuk mengetahui parameter tanah dan batuan di area tersebut. Berdasarkan semua informasi yang didapatkan, dapat direncanakan pembangunan infrastruktur yang lebih siap dalam menghadapi perubahan cuaca dan kondisi bawah permukaan. Pengamatan rinci seperti ini memungkinkan usaha mitigasi yang lebih baik dengan memfokuskan usaha penguatan pada daerah yang rawan bahaya saja, dan tidak perlu mengkategorikan keseluruhan daerah sebagai daerah bahaya pergerakan tanah.

\section{UCAPAN TERIMA KASIH}

Kami mengucapkan terima kasih atas kesempatan yang diberikan oleh Pemerintah Daerah Kabupaten Sukabumi untuk melakukan penelitian di kompleks perkantoran Jajaway. Dana penelitian sepenuhnya berasal dari DIPA tahun 2014 Pusat Penelitian Geoteknologi. Akusisi data dilakukan oleh tim survei: Adde Tatang, Amar, Fuad Firmansyah, Wahyudin, Nyanjang, dan Dede Rusmana. Juga terima kasih untuk bantuan akomodasi dari Edi Hidayat dan Aryo Dwi Handoko.

\section{DAFTAR PUSTAKA}

Bellanova, J., Calamita, G., Giocoli, A., Luongo, R., Macchiato, M., Perrone, A., 2018. Electrical resistivity imaging for the characterization of the Montaguto landslide (Southern Italy). Eng. Geol., 243, 272-281. doi:10.1016/j.enggeo.2018.07.014

Cebulski, J., Pasierb, B., Wieczorek, D., Zieliński, A., 2020. Reconstruction of landslide movements using Digital Elevation Model and Electrical Resistivity Tomography analysis in the Polish Outer Carpathians. Catena, 195, 104758. doi:10.1016/j. catena.2020.104758

Effendi, A.C., Kusnama, Hermanto, B., 1998. Peta Geologi Lembar Bogor, Jawa Barat. Pusat Survey Geologi Indonesia.

Grandis, H., 2009. Pengantar Pemodelan Inversi Geofisika. Himpunan Ahli Geofisika Indonesia (HAGI).

Highland, L.M., Bobrowsky, P., 2008. The landslide Handbook - A guide to understanding landslides. US Geol. Surv. Circ. 1-147. doi:10.3133/cir1325

Keskinsezer, A., Dağ, E., 2019. Investigating of soil features and landslide risk in WesternAtakent (Istanbul) using resistivity, MASW, Microtremor and boreholes methods. Open Geosci. 11, 1112-1128. doi:10.1515/geo2019-0086

Ling, C., Xu, Q., Zhang, Q., Ran, J., Lv, H., 2016. Application of electrical resistivity tomography for investigating the internal structure of a translational landslide and characterizing its groundwater circulation (Kualiangzi landslide Southwest China ). J. Appl. Geophys. 131, 154-162. doi:10.1016/j. jappgeo.2016.06.003

Putra, M.H.Z., Kartiko, R.D., Soemantidiredja, P., Sadisun, I.A., Tohari, A., 2020. Pengaruh Zona Jenuh Air Terhadap Kestabilan Lereng Di Weninggalih, Kabupaten Bandung Barat. Ris. Geol. dan Pertamb. 30, 119. doi:10.14203/risetgeotam2020.v30.1086

PVMBG, 2020. Peta Zona Kerentanan Gerakan Tanah Kota dan Kabupaten Sukabumi, Propinsi Jawa Barat. 
Radbruch-Hall, D.H., Varnes, D.J., 1976. Landslides - Cause and effect. Bull. Int. Assoc. Eng. Geol. 13, 205-216. doi:10.1007/ BF02634797

Rauff, K.O., Abir, I.A., Perissin, D., 2020. Characterisation of Landslide using InSAR Technique and Electrical Resistivity Method at Paya Terubong, Malaysia. J. Indian Soc. Remote Sens. 48, 1223-1236. doi:10.1007/ s12524-020-01150-3

Rodi, W., Mackie, R.L., 2001. Nonlinear conjugate gradients algorithm for 2-D magnetotelluric inversion. Geophysics 66, 174-187. doi:10.1190/1.1444893

Schulz, W.H., Coe, J.A., Ricci, P.P., Smoczyk, G.M., Shurtleff, B.L., Panosky, J., 2017. Landslide kinematics and their potential controls from hourly to decadal timescales: Insights from integrating ground-based InSAR measurements with structural maps and long-term monitoring data. Geomorphology, 285, 121-136. doi:10.1016/j.geomorph.2017.02.011

Sugianti, K., Sukristiyanti, S., Tohari, A., 2016. Model Kerentanan Gerakan Tanah Wilayah Kabupaten Sukabumi Secara Spasial Dan Temporal. J. Ris. Geol. dan Pertamb. 26, 117. doi:10.14203/risetgeotam2016.v26.270 Telford, W.M., Geldart, L.P., Sheriff, R.E., 1990. Applied Geophysics, $1^{\text {nd }}$ (ed.). Cambridge University Press.

Van Bemmelen, R.W., 1949. The Geology of Indonesia. General Geology of Indonesia and Adjacent Archipelagoes. 